Vol. 5, No. 1 | January - June 2021

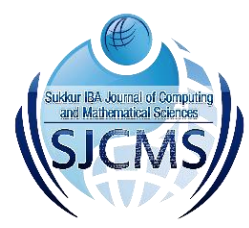

\title{
Impact Assessment of Urban Pull-factors on Uncontrolled Urbanization: Evidence from Pakistan
}

\author{
Hassam Bin Waseem ${ }^{1}$, Mir Aftab Hussain Talpur ${ }^{1}$
}

\begin{abstract}
:
Uncontrolled urbanization is a global phenomenon, currently sweeping through developing countries like Pakistan. Being the 6th most populous country, its strategic urban locations receive a humongous migrant influx. A prime victim is Hyderabad, Pakistan, the Sindh's second-largest urban settlement after Karachi that experiences enormous urban problems due to immense urbanization. Hence, the study aims to propose policy recommendations to curtail urbanization rate of Hyderabad, Sindh and Pakistan. The objective of this study is to measure the impacts of pull-factors in perception of migrants so that the policy recommendations could be proposed on most responsible factors. For this study, 3 urban Talukas (a district's subdivision) of district Hyderabad were selected. While a sample of 400 migrants was procured using purposive and snowball sampling techniques for the questionnaire survey. Utilizing a large survey data, the results were obtained using descriptive statistics and multiple regression. Results showed a significant impact of economic and socio-cultural pull-factors like better employment opportunities $(0.152)$, higher income probability $(0.222)$, job security $(0.779)$, easy access to facilities $(0.763)$, better outlook and hope for the future $(0.324)$, and comfortable and diverse lifestyle (0.159) in causing immense urbanization. Nevertheless, desire for independence and access to basic social services appeared to have a negative impact. The proposed policy recommendations on significant pull-factors could be considered as a first step to handle uncontrolled urbanization. Moreover, the study is significant as it particularly contributes to apprehend Hyderabad's various interrelated urban issues. In general terms, this research can be considered as a role model for high-density third world cities suffering from relatable urban malaise.
\end{abstract}

Keywords: Uncontrolled Urbanization; Pull-factors; Multiple Regression; Third World Cities; Policy Recommendations

\section{Introduction}

Uncontrolled urbanization is a global urban problem, which can be defined as, "the process of rural to urban migration complementing the immense and rapid growth of urban areas" [1]. Hypothesize as a consequence of population increase, industrialization, technology reforms, infrastructure services, and fiscal advancements; it specifically leads to urban transformations [2, 3]. Being the most vital element of internal migration and hasty urban growth; it is an influential sign of regional disparity concerning economy and lifestyle [4, 5]. Intrinsically, the process involves urban development activities as poverty-driven rural laborers satisfy the huge labor requirement of urban centers [6].

Urbanization is a multi-dimensional event that occurred for numerous whys and

${ }^{1}$ Mehran University of Engineering \& Technology, Jamshoro, Sindh, Pakistan Corresponding Author: hassam.waseem@gmail.com 
wherefores. Its causes and factors may differ between the countries and inside a country too. Irrespective of its several stages such as suburbanization and ex-urbanization, the phenomenon leads to multifaceted urban spatial structure, declining agricultural land, deviating employment and residential locations, and pressures on urban and rural livelihoods [7-10]. Mostly, the phenomenon relies on four factors, i.e. push, pull, stay, and return; of which, pull-factors are the most prominent determinants $[11,12]$. They convince a person to attempt migration in search of better economic and socio-cultural conditions for him/herself and/or for their family [3]. Furthermore, several phenomena of urban areas like mono-centric, multi-centric, dwindling and flourishing, refine and shape their decisions [13]. Complementing this, the variances in migration rates directed discrepancies in physical and societal patterns in the city centers [14]. Thus, having profound impacts on urban areas, its linkages, and overall urban expansion.

In the context of third world countries, the phenomenon of urbanization is conceived as an illimitable concern that results in strained health and education budgets, and complicated unemployment level reduction [15, 16]. Though the increase in urbanization aids in terms of poverty reduction and economic growth $[10,16,17]$. Nonetheless, the snags are coupled with urban issues, like ever-expanding slums, scarce basic urban services, inadequate housing, overpopulation, ill-planning of shelters and industries along with nonconformity of land use bylaws/codes/standards [18]. Furthermore, the phenomenon faded urban-suburban rift that led to urban sprawl [19].

The urban planner's perspective in this dilemma is the exaggeration of land competition on urbanization focal points either through land development or redevelopment. They are concerned as its consequences would affect third world countries by soaking up physical, economic, and socio-cultural transformations in the form of urban activities [20]. The intrusion of valuable peri-urban land is the climax of this paradigm, i.e. an issue affecting sustainability [21]. This dilemma is termed as 'Desakota' referring to the concentrated blend among agricultural and non-agricultural land uses on urban fringes [22]. The migration within third world countries (such as, Pakistan) is usually grounded on pull-factors that raise questions regarding the linkages between urbanization and several pull-factors [23]. This objectiveoriented migration makes urbanization as Pakistan's recent developmental issue, for which, no migration profile is formulated [3, 24].

The immense urbanization pace is on the verge these days in Pakistan. It would continue at a faster pace for upcoming years as Pakistan's economy is escalating and reforming [25]. Surprisingly, no one portrayed pull-factors, such as rural environmental degradation, and so on, as its major drivers [26]. Preliminary results of the Pakistan Census 2017 declared one of the provinces of Pakistan, i.e. Sindh as the most urbanized province with $52.02 \%$ urban population, and Hyderabad as the second most urbanized district, after Karachi with 1,834,371 urbanites [27]. As mentioned earlier, its strategic location attracts more populace flow making it a victim of urban agglomeration. This worst scenario of uncontrolled urbanization was also highlighted in the Hyderabad Master Plan (2007-2020). The master plan document clearly declared that urban pull is causing mushroom growth complemented with urban issues, like over-stretched and imbalanced infrastructure, over-burdened facilities, bad condition of roads, traffic problems, and so on [28]. Moreover, the extreme flow of migrants towards Hyderabad validates a strong urban pull, as well as the presence of problematic conditions discussed by various authors globally [16, 18]. Siddiqi [16] portrays urbanization as two-stage process wherein the economic migrants get settled in informal settlements with an informal job first, and then they become permanent resident within the main urban core. By using correlation technique on a data obtained from a random sample, the author explained a positive correlation between education and migration 
in Pakistan. Lanrewaju [18] assessed the housing quality and impacts of urbanization on environmental degeneration of urban built environment in Nigeria. The author used frequency distribution on secondary data including population census, official documents, and literature to determine urbanization as a root cause of problems such as overburdened infrastructure, overcrowding, and substandard housing, etc.

The new escalated city-making courses and absence of migration profile demand further clarification on this cliché [3, 29]. Scholars are looking scrupulously to the constraints, opportunities, and public reaction with respect to the imposed urban situation worldwide. In the context of third world countries, particularly Pakistan, this study offered new dawn and aims to propose policy recommendations on significant economic and socio-cultural pull-factors via a set of predefined pull-factors derived from the literature [30]. These policy recommendations would make significant contributions in curtailing uncontrolled urbanization and assists in harnessing it before the condition exacerbates. Furthermore, solutions could be replicated in any third world city going through the unfettered urbanization pace and haphazard urban growth.

The upcoming section introduces the study area and its relevance to the topic. It proceeds to reveal the urbanization timeline and discusses why Hyderabad is an eye-catching place for migrants. For a comprehensive background, it continues to describe the tactics and tools exercised to derive the results with accuracy and authenticity. Afterward, the sections of results and discussion highlight the causes of urbanization and its core contributors. At last, the section of policy recommendations grabs the concerns of policy-makers, scholars, and urban planners having a keen interest in calming urbanization pace. It offers optimum suggestions whose inclusion in the policies of urban planning and development, urban management, and urban governance could result in transforming Hyderabad and similar third-world cities to a place that fosters the economy and nurture its urbanites.

\section{Methodology}

The detailed information regarding the area of interest, the data collection procedure, the data collection instrument, and the data analysis method is discussed hereafter.

\subsection{Study Area}

The urbanization evidence for this study was obtained from three urban Talukas (a district's subdivision) of district Hyderabad. Hyderabad is Pakistan's $4^{\text {th }}$ largest city and $2^{\text {nd }}$ of the Sindh province, located 24 $46^{\prime}$ and 26 $06^{\prime}$ Latitudes and 68 $16^{\prime}$ and 6859' Longitudes [31]. As shown in Fig. 1, Hyderabad is divided into 4 Talukas, namely, Hyderabad City, Latifabad, Qasimabad, and Hyderabad Rural. As urbanization is usually observed in the major urban centers, the study was solely confined to urban Talukas excluding suburbs and cantonment areas. The study area can be seen in Fig. 1 .

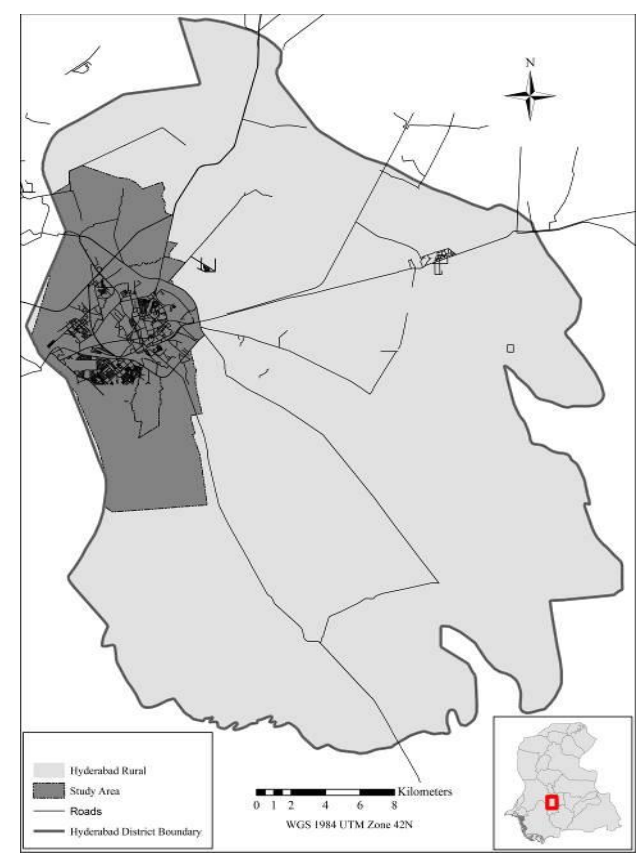

Fig. 1. Map of Hyderabad District 


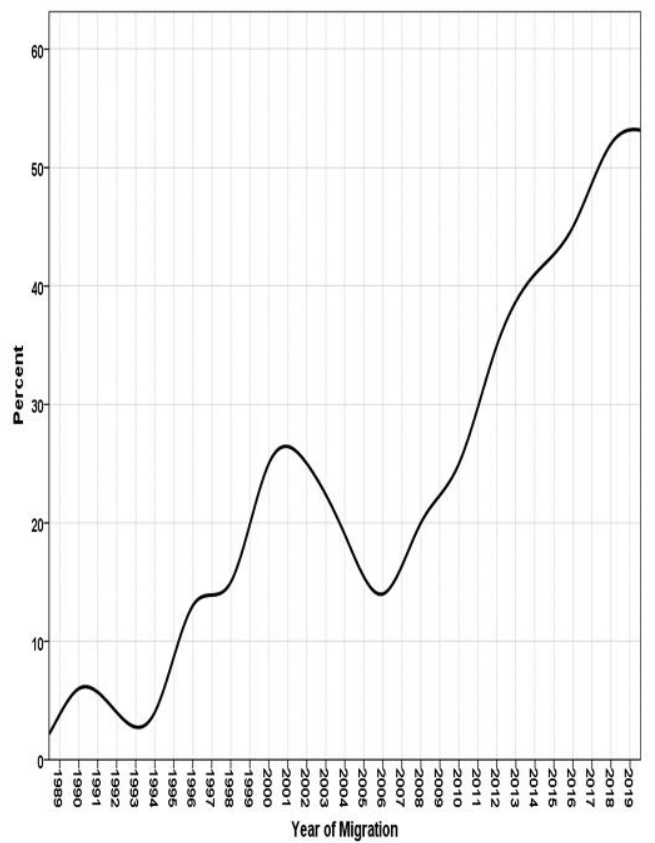

Fig 2. Hyderabad's Urbanization Trend

Since Pakistan's independence, Hyderabad is among those areas that dominate the urbanization scene. Its regional connectivity, urban facilities, and hope for a better life are

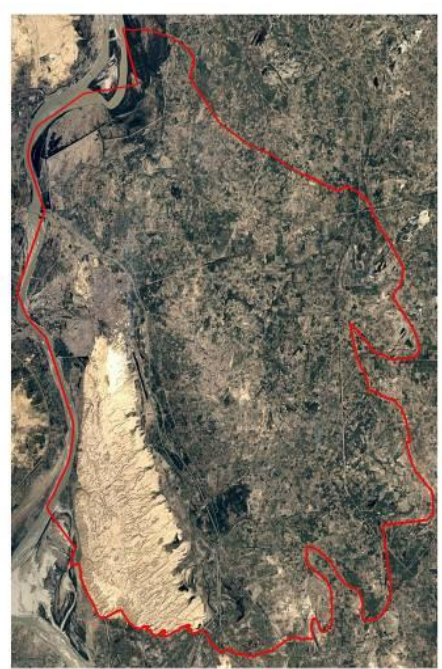

(a) 2000

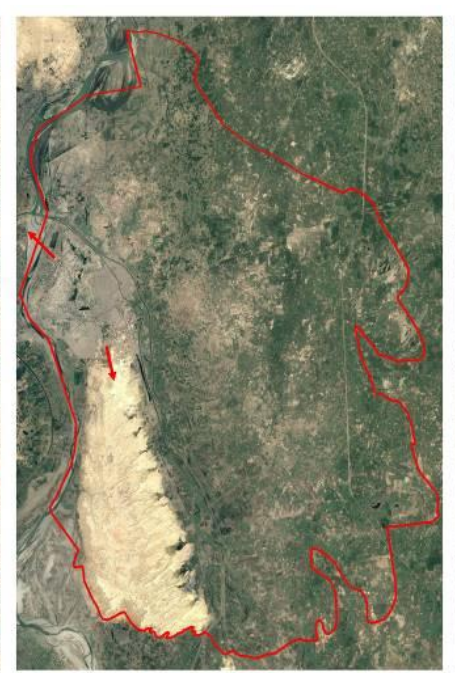

(b) 2010

core reasons of urbanization that contributed $12 \%$ of local migrants [32]. Hyderabad's critical setting accelerates urbanization pace ensuing urban glitches stated earlier. In 1998, the district with 8 Talukas had 2,891,488 population and 94,158-lifetime migrants [31]. Whilst, the district with 4 Talukas and 52 Union Councils (the lowest tier of government, a subdivision of Taluka) has 1,834,371 urbanites [27]. Fig.2 shows the recorded years in which the respondents moved to Hyderabad. The graph is significant as it assists to understand the Hyderabad's urbanization trend. As illustrated in Fig. 2, the urbanization pace received a backlash from 2008-2010 due to a severe disturbance in law and order situation. However, the annual flooding from 2010 and onwards along with some better law and order situation gives urbanization a humungous increase and open the doors of immense urbanization towards Hyderabad.

Fig. 2 clearly depicts that the urbanization pace is not stopped yet. The facts are drastically increasing; and poor planning practices, plan implementation's inefficiency, as well as the vacuum created by loopholes and contradictions in governing power, would let it increase on and on [33]. Fig. 3 illustrates a timeline of urbanization-led urban expansion

Fig 3. Hyderabad's Urban Expansion Timeline (2000-2020) 
in Hyderabad from 2000 to 2020. Fig. 3 (b) clearly shows that in 2010 the city starts expanding towards Taluka Qasimabad and Taluka Latifabad. Whereas, in the year 2020 (Fig. 3 (c)), another dimension (i.e. towards Hyderabad Rural Taluka) was added to the urban expansion. Increase in the density of urban built environment can also be observed in the figure. An important aspect behind this urbanization-led urban expansion is the influences of private real estate developers are complicating the matter. Indeed, they are responding to shelter needs, however, it contributes to the excessive urban population, more dense settlements, and unjustifiable urbanization patterns [34-36]. Like Karachi's urbanization dilemma, poor migrant families usually reside in outlying informal settlements on Taluka boundaries, causing agricultural land misuse and pushing the Taluka boundaries outward [37]. The entire scenario is led by economic migrants and termed as peasant-dominated urbanization, along with the job mobility of impermanent rural migrants [38]. To conclude, economic and socio-cultural pull-factors were found as main drivers for the uncontrolled urbanization process. These clichés convinced the researchers to conduct the study here with an aim to suggest optimum policy recommendations for harnessing urbanization's flow and protecting the area from the urban explosion.

\subsection{Theoretical Framework}

Following the footprints of previous researches, this study focuses on a multidimensional theoretical framework to explain the economic and socio-cultural aspects of immense urbanization $(\mathrm{Gu}$ et al. 2014). The study involves a dependent variable, i.e. urbanization (pull-factors) and a total of 8 independent variables that further categorized into economic, and socio-cultural pull-factors, as shown in Table 1. As poverty is prevailing throughout the country, economic instability is getting acute in rural areas. The rural inhabitants tend to move in search of employment opportunities to central districts. Being an economic hub of Sindh province after Karachi, Hyderabad is the most preferred location for economic migrants to move. Apparently, it offers more employment opportunities either formal or informal in all fields of work. Thus, the probability of getting a job in Hyderabad is more than in other districts of Sindh excluding Karachi. Furthermore, the vast demand for almost every product ensures the continuous supply of the goods and services that makes the job secure. Therefore, economic variables like better employment opportunities $\left(\mathrm{X}_{1}\right)$, higher income probability $\left(\mathrm{X}_{2}\right)$, and job security $\left(\mathrm{X}_{3}\right)$ were selected considering the current economic situation of the country.

In some cases, people migrate to urban areas because they might want to live their life without any socio-cultural taboos, limitations, and restrictions and cities provide shelter to people seeking freedom. Unlike other districts of Sindh province, Hyderabad is preferred as the best place for students due to the presence of numerous excellent schools, colleges, and vocational training institutes; but its proximity to the three best public sector universities of Pakistan could be the most highlighted factor. Likewise, it has better hospitals, better living conditions, better transportation facilities, more amusement places, and easy access to other utilities and services. The easiness in accessing such facilities make Hyderabad a way more comfortable place to live contrary to other districts. Such a scenario results in the selection of socio-cultural variables like desire for independence $\left(\mathrm{X}_{4}\right)$, better outlook and hope for the future $\left(\mathrm{X}_{5}\right)$, access to basic social services $\left(\mathrm{X}_{6}\right)$, comfortable and diverse lifestyle $\left(\mathrm{X}_{7}\right)$, and easy access to facilities $\left(\mathrm{X}_{8}\right)$. Thus, Table 1 contains a list of predefined variables of urbanization from the literature that emerged as core encouragers of urbanization. Several researchers used bits and pieces of Table 1 to examine the impact of urbanization in their respective areas of interest. However, a collective impact assessment of these variables would be a more comprehensive and multidimensional analysis to understand urbanization from a new perspective. Also, as the major contributors of urbanization with respect to Hyderabad are still unknown, the respective impacts of these variables would 
help in understanding the urbanization paradigm of Hyderabad. To conclude, pullfactors could be considered as the critical encouragers behind Hyderabad's uncontrolled urbanization. By testing the aforesaid statement, the study intends to propose policy recommendations on significant pull-factors based on the study design discussed henceforth.

Table I. Study Variables

\begin{tabular}{|c|c|}
\hline Variables & Sources \\
\hline $\begin{array}{l}\text { Better } \\
\text { employment } \\
\text { opportunities }\end{array}$ & $\begin{array}{l}\text { Turan and Beşirli [2], } \\
\text { Akhter [4], Harris and } \\
\text { Todaro [6], Zax [8], Crow } \\
\text { [11], Ishtiaque and Sofi } \\
\text { Ullah [12], Haas and } \\
\text { Osland [13], Jones [15], } \\
\text { Government of Pakistan } \\
\text { [32], Verter and Darkwah } \\
\text { [39], George and } \\
\text { Shyamsundar [40], } \\
\text { McCool and Kruger [41], } \\
\text { Amphune and Enaro [42], } \\
\text { Cobbinah, et al. [43], } \\
\text { Sridhar, et al. [44], } \\
\text { Chakma and Akhy [45], } \\
\text { Thet [46], Martin and } \\
\text { Zuercher [47] }\end{array}$ \\
\hline $\begin{array}{l}\text { Higher income } \\
\text { probability }\end{array}$ & $\begin{array}{l}\text { Harris and Todaro [6], } \\
\text { Crow [11], Ishtiaque and } \\
\text { Sofi Ullah [12], Lanrewaju } \\
\text { [18], Morinière [26], } \\
\text { Government of Pakistan } \\
\text { [32], Verter and Darkwah } \\
\text { [39], George and } \\
\text { Shyamsundar [40], } \\
\text { McCool and Kruger [41], } \\
\text { Sridhar, et al. [44], Thet } \\
\text { [46], Grabova, et al. [48], } \\
\text { Zweig, et al. [49] }\end{array}$ \\
\hline Job security & $\begin{array}{l}\text { Crow [11], Lanrewaju } \\
\text { [18], Verter and Darkwah } \\
\text { [39], Thet [46] }\end{array}$ \\
\hline $\begin{array}{l}\text { Desire for } \\
\text { indepence }\end{array}$ & $\begin{array}{l}\text { Crow [11], Van Noorloos } \\
\text { and Kloosterboer [29], } \\
\text { Government of Pakistan } \\
\text { [32], Thet [46] }\end{array}$ \\
\hline $\begin{array}{l}\text { Better outlook and } \\
\text { hope for the future }\end{array}$ & $\begin{array}{l}\text { Crow [11], Van Noorloos } \\
\text { and Kloosterboer [29], } \\
\text { Verter and Darkwah [39], } \\
\text { McCool and Kruger [41], }\end{array}$ \\
\hline
\end{tabular}

(pp. $37-52$ )

\begin{tabular}{|c|c|}
\hline & $\begin{array}{l}\text { Amphune and Enaro [42], } \\
\text { Cobbinah, et al. [43], Thet } \\
\text { [46], Grabova, et al. [48] }\end{array}$ \\
\hline $\begin{array}{l}\text { Access to basic } \\
\text { social services }\end{array}$ & $\begin{array}{l}\text { Turan and Beşirli [2], } \\
\text { Akhter [4], Crow [11], } \\
\text { Lanrewaju [18], Amphune } \\
\text { and Enaro [42], Cobbinah, } \\
\text { et al. [43], Thet [46] }\end{array}$ \\
\hline $\begin{array}{l}\text { Comfortable and } \\
\text { diverse lifestyle }\end{array}$ & $\begin{array}{l}\text { Turan and Beşirli [2], } \\
\text { Crow [11], Verter and } \\
\text { Darkwah [39], George and } \\
\text { Shyamsundar [40], } \\
\text { Amphune and Enaro [42], } \\
\text { Thet [46], Grabova, et al. } \\
\text { [48], Zweig, et al. [49] }\end{array}$ \\
\hline $\begin{array}{l}\text { Easy access to } \\
\text { facilities }\end{array}$ & $\begin{array}{l}\text { Turan and Beşirli [2], } \\
\text { Crow [11], Jones [15], } \\
\text { Amphune and Enaro [42], } \\
\text { Chakma and Akhy [45], } \\
\text { Thet [46] }\end{array}$ \\
\hline
\end{tabular}

\subsection{Sampling and Data Collection}

The study's sampling plan comprises of mixed research methodology, including, Purposive and snowball sampling techniques for collecting questionnaire survey data $[12,42$, 50-56]. The purposive sampling was used to get the response only from the permanently migrated persons, whereas the snowball sampling assists in contacting more migrants as referred by the previous respondent. Due to the unavailability of detailed Census 2017 results, the researchers derived sample size from an estimated present year population. By applying the simplified sample size formula by Yamane [57], 400 migrants' sample at a $95 \%$ confidence interval was decided to work on. To collect authentic and detailed information from the respondents, the data were collected using a face-to-face questionnaire survey. The questionnaire was developed under the supervision of academia and field experts. Ethicality was ensured by informing the respondents about the survey purpose. They were also ensured about the anonymization of the questionnaire to void their doubts about privacy. The questionnaire was structured into 2 main sections. Section 1 was intended to collect socio-demographic information, while section 2 recorded their perception regarding the responsibility of 
pull-factors in causing urbanization on a Likert scale. The 4-point Likert scale based questions were organized to evaluate the migrants' perception from $1=$ not at all responsible, to 4=completely responsible [58]. Frequency distribution was used to calculate the socio-demographic variables. Furthermore, responses on another variable of urbanization (pull-factors) were recorded on a similar 4-point Likert scale to measure the responsibility of pull-factors in causing uncontrolled urbanization in the perception of migrants. This variable was used as a dependent variable with formerly identified independent variables to construct a multiple regression model to determine the factors influencing urbanization [3, 12, 39, 51, 56, 59, 60]. At last, the collected data was scrutinized to produce results that are discoursed hereafter.

\section{Results}

Before discussing the impact of urban pullfactors on uncontrolled urbanization, a glimpse on the urbanization profile of Hyderabad, Pakistan, is illustrated in Table 2, for better understanding of results. As illustrated in Table 2, it was found that most of the respondents $(54.66 \%)$ were young (16-25 years old) when they migrated to Hyderabad, while $39.80 \%$ respondents were less than 15 years old, $5.29 \%$ respondents migrated in mature age (26-35 years) and only $0.25 \%$ migrated in more than 36 years age group. The majority of respondents were university graduates $(63.70 \%)$, while the rest had attained higher secondary $(24.30 \%)$, secondary $(5.80 \%)$, and primary education $(4.80 \%)$ only. Most of the respondents settled in Qasimabad Taluka, which constituted about $51.64 \%$ of the total population. Followed by Qasimabad, $31.39 \%$ of respondents settled in Hyderabad city Taluka, while the least $(16.96 \%)$ settled in Latifabad Taluka. Moreover, most of the respondents had their own houses (54.20\%), against rented ones $(45.80 \%)$ which means that most of the respondents became permanent residents of that area.
Table II. Socio-demographic characteristics of the respodents

\begin{tabular}{|l|l|c|}
\hline \multicolumn{2}{|c|}{$\begin{array}{c}\text { Socio-demographic } \\
\text { Characteristics }\end{array}$} & Percentage \\
\hline \multirow{4}{*}{$\begin{array}{l}\text { Age (during } \\
\text { migration) }\end{array}$} & Less than 15 & $54.66 \%$ \\
\cline { 2 - 3 } & $16-25$ & $39.80 \%$ \\
\cline { 2 - 3 } & $26-35$ & $5.29 \%$ \\
\cline { 2 - 3 } & $\begin{array}{l}\text { More than } \\
36\end{array}$ & $0.25 \%$ \\
\hline \multirow{4}{*}{$\begin{array}{l}\text { Education } \\
\text { Level }\end{array}$} & University & $63.70 \%$ \\
\cline { 2 - 3 } & $\begin{array}{l}\text { Higher } \\
\text { secondary }\end{array}$ & $24.30 \%$ \\
\cline { 2 - 3 } & Secondary & $5.80 \%$ \\
\cline { 2 - 3 } & Primary & $6.20 \%$ \\
\hline \multirow{2}{*}{$\begin{array}{l}\text { Migrated } \\
\text { Taluka }\end{array}$} & Qasimabad & $51.64 \%$ \\
\cline { 2 - 3 } & Latifabad & $16.96 \%$ \\
\cline { 2 - 3 } & $\begin{array}{l}\text { Hyderabad } \\
\text { City }\end{array}$ & $31.39 \%$ \\
\hline \multirow{4}{*}{$\begin{array}{l}\text { Ownership } \\
\text { status }\end{array}$} & Owned & $54.20 \%$ \\
\cline { 2 - 3 } & Rented & $45.80 \%$ \\
\hline
\end{tabular}

\subsection{Pull-factors Influencing Uncontrolled Urbanization}

The measuring rod used for suggesting policy recommendations were the impacts obtained from the statistical modeling technique, i.e. multiple linear regression (MLR). Multiple regression model was estimated to determine the best linear combination of 8 urban pull-factors for predicting their influences in causing uncontrolled urbanization. All economic and socio-cultural pull-factors were found highly responsible for causing uncontrolled urbanization $(p<0.01)$, except comfortable and diverse lifestyle that was found significant at $p<0.05$ as shown in Table 3. Model heteroscedasticity was tested using BreuschPagan [61] and Koenker [62] tests, where the model was found heteroscedasticity robust. 
As the selected economic and sociocultural pull-factors significantly predicted the dependent variables, the regression model was found a good fit of the data. The $\mathrm{R}^{2}$ value $(0.861)$ indicates that $86.1 \%$ of the variance in the responsibility of pull-factors to cause urbanization was explained by the model. The tolerance value of the coefficients of predictors was recorded well at over $0.139\left(1-\mathrm{R}^{2}\right)$. This shows an extremely low level of multicollinearity among the model predictors. According to the $\beta$ coefficients represented in Table 3, a significant role of economic and socio-cultural pull-factors was observed in influencing urbanization towards Hyderabad. Where all economic pull-factors (better employment opportunities, higher income probability, and job security) were found statistically significant and emerged as core boosters of urbanization that retain return migration and encourage economic migrants to mingle in the urban fabric. Furthermore, all socio-cultural pull-factors were found statistically significant and appeared as significant propellers of urbanization except desire for independence and access to basic social services as they emerged as negative contributors. Such negative impacts could be justified as the people of Pakistan (especially Sindh) are strongly attached to their cultural ties and solely owns and follows it. They are also free to practice their traditional and religious practices everywhere. Hence people do not seek shelter in cities to escape from their culture and tradition.
Moreover, the basic social services are available in almost every district of Pakistan, especially the neighbouring districts of Hyderabad. Thus, such factors do not influence a person to migrate. By substituting the coefficients of Table 3 in standardized multiple regression equation, the regression model could be expressed as.

$Y=0.498+0.152 X_{1}+0.222 X_{2}+0.779 X_{3}-$
$0.908 X_{4}+0.324 X_{5}-0.615 X_{6}+0.159 X_{7}+$
$0.763 X_{8}$

\section{Discussion}

For many decades, Pakistan has not experienced a dynamic transformation that could push its major cities towards the path of prosperity and development. Indeed, efforts were tempted, but the urban problems are either misunderstood or the role of planning is taken for granted. As a result, people are continuously migrating to urban areas for several reasons. A study in Pakistan revealed that such migration behavior is driven by economic, social, and cultural pull-factors [50]. This situation matches the study findings as many economic and socio-cultural pullfactors were found responsible to frame Hyderabad as a highly dense and urbanized setting. Backing the results of Bahuguna and Belwal [60], Ahmad, et al. [63], Zi [64], Ajaero, et al. [65], the study found economic pull-factors (better employment opportunities, higher income probability, and job security) as

Table III. Regression Coefficients for pull-factors

\begin{tabular}{|c|c|c|c|c|c|}
\hline \multicolumn{6}{|c|}{$R=0.928, R^{2}=0.861$, Adjusted $R^{2}=0.858$, Std. Error of the Estimate $=0.123$} \\
\hline Variables & Label & $\begin{array}{c}\text { Unstandardized } \\
\text { Coefficients }\end{array}$ & $\begin{array}{c}\text { Std. } \\
\text { Error }\end{array}$ & $\mathbf{t}$ & Sig. \\
\hline Constant & & 0.498 & 0.101 & 4.930 & 0.000 \\
\hline Better employment opportunities & $\mathrm{X}_{1}$ & 0.152 & 0.032 & 4.698 & 0.000 \\
\hline Higher income probability & $\mathrm{X}_{2}$ & 0.222 & 0.045 & 4.903 & 0.000 \\
\hline Job security & $\mathrm{X}_{3}$ & 0.779 & 0.092 & 8.491 & 0.000 \\
\hline Desire for independence & $\mathrm{X}_{4}$ & -0.908 & 0.097 & -9.357 & 0.000 \\
\hline Better outlook and hope for the future & $\mathrm{X}_{5}$ & 0.324 & 0.083 & 3.919 & 0.000 \\
\hline Access to basic social services & $\mathrm{X}_{6}$ & -0.615 & 0.085 & -7.236 & 0.000 \\
\hline Comfortable and diverse lifestyle & $\mathrm{X}_{7}$ & 0.159 & 0.051 & 3.126 & 0.002 \\
\hline Easy access to facilities & $\mathrm{X}_{8}$ & 0.763 & 0.052 & 14.658 & 0.000 \\
\hline
\end{tabular}


the most common triggers of uncontrolled urbanization because;

i. The secondary and tertiary cities of Sindh are going through the phases of negligence, and urban bias. This gives rise to rural push as people are giving up their hopes and faith from local government that was intended only to facilitate them.

ii. Problems, such as the outdated irrigation system, the water shortage, illegal agricultural water supply, and the monopoly of agriculture market stakeholders are creating hurdles for farmers. As a result, growers are forced to leave their native places and move to urban areas like Hyderabad, as their economic diversity offers many secure employment opportunities. Moreover, as the rural push tends to increase urban pull, which attracts many economic migrants and job seekers towards Hyderabad.

The literature also portrayed socio-cultural pull factors as a prominent reason for rural to urban migration. Studies from Myanmar, Malaysia, and Pakistan revealed hope for better outlook as a strong pull-factor, which resembles the study findings [3, 46, 66]. Unlike Hyderabad, the secondary and tertiary cities of Sindh do not have a variety of urban services. This was clearly observed from the results as easy access to facilities emerged as the strong contributor for immense urbanization. Contrary to Sindh secondary and tertiary cities, Hyderabad possesses many facilities that could enhance the socioeconomic outlook of migrants. It has a better transportation infrastructure. Though public transport is unavailable, still it offers a good communication network within and among its Talukas that increases the interconnectivity of activity centers and promotes industrial productivity. Another study from India found influences of education level and desire of attaining higher education as a strong propeller of urbanization [44]. Results, however, show an agreement with the statement. Numerous quality pedagogy institutes exist in Hyderabad that attracts the youth either to earn by teaching or to study.
Also, its proximity to three famous public sector universities, namely, Mehran University of Engineering and Technology (MUET), University of Sindh (UoS), and Liaquat University of Medical and Health Sciences (LUMHS), makes it an optimum location for migrants to reside. In addition, it facilitates migrants from its vast commercial and recreational amenities accompanied by a peaceful atmosphere.

Furthermore, findings indicate the negative impact of desire for independence and access to basic social services. As the joint family system is a common cultural element in almost every community of Pakistan, people often prefer to live with their parents and siblings. Likewise, neither the elders encourage them to live separately, nor they are willing to move. They also own their culture and traditions. Thus, they do not seek shelter in urban areas to live independently. Additionally, as the local governments are ensuring the provision of basic social amenities, people do not prefer to move due to such reasons.

The aforesaid significant pull-factors along with the influences of rural push attract migrants towards Hyderabad. Hope for a better life convinces them to stay as strategic urban locations like Hyderabad are places where dreams come true. As the backlog of preceding pull-factors is rising in Sindh secondary and tertiary cities at an alarming rate. Similarly, urbanization paradigms tend to exceed their tolerable limit, especially in urban settings like Hyderabad, making the situation worse.

To conclude, the analytical findings of the study quantify the economic and socio-cultural impacts on Hyderabad's uncontrolled urbanization. Pull-factors, such as, better employment opportunities (0.152), high income probability (0.222), job security (0.779), better outlook and hope for the future (0.324), comfortable and diverse lifestyle (0.159), and easy access to facilities (0.763), emerged as the significant propellers of urbanization. The emergence of these pullfactors validates the achievement of study's objective. Furthermore, the interpretation of outcomes helped to understand the reasons and 
consequences of immense urbanization in Hyderabad. Additionally, the study findings deliver a firm baseline to propose optimum policy recommendations. Thus, assists in achieving the study's aim.

\section{Policy Recommendations}

This study is an initiative towards urbanization control in Hyderabad, which offers a firm foundation to control urban sprawl and haphazard growth. In addition, this research could serve as a helping hand for other urbanization studies conducted worldwide with a special emphasis on third world cities. Considering the principles of feasibility, ethicality, and suitability in proposing policy recommendations, they are structured by keeping in view the major findings and urbanization consequences. The phrase Sindh secondary and tertiary cities refer to Sindh's second-order (Sukkur, and Larkana) and third-order (Mirpurkhas, Nawabshah, Jacobabad, Shikarpur, Tando Adam, and Khairpur) cities. The most optimum policy recommendations that could assist to curtail rapid urbanization and its related issues in the Hyderabad district and other third world urban areas are described henceforth.

\subsection{Policy Recommendations for Economic Pull-factors}

Policymakers need to understand that facilitating the rural areas with social utilities and services would not halt the migrant's stream except the new openings for the working class are introduced in conjunction with those amenities. The complete implementation of development / strategic / local plans should also be ensured, as the development works can widen employment opportunities for labor and technically-sound people. Also, several practical strategies could be adopted to identify the specialized products of Sindh secondary and tertiary cities along with the establishment of specialized marketplaces for native workers that intensify their potential and reduces the urban-rural income gap that generates 'urban pull'.
Advancements in joint ventures between research universities and industrious fiscal divisions could be made to help encourage high-value employment. In addition, provision of more fiscal inducements and professional training in Sindh secondary and tertiary cities could also reverse the urbanization and hold experts and academically qualified personnel in their respective origins. Most importantly, the participation of women and differentlyabled persons should be encouraged in income generation activities through the provision of long-term changes in traditional employment values, mainly convenient job natures, like virtual jobs, and remote work, etc. Their expertise should be directed toward information technology (IT), freelancing, innovation, and entrepreneurship to promote businesses and online earning.

Agricultural and agriculture-based industries, like poultry, fisheries, horticulture, dairy should be promoted, and emphasis should give on promoting small-scale mineral, forest-based and agro-processing industrial units and industrial parks. Agriculture based industries may be given special incentives. The agencies like Sui Southern Gas Company (SSGC), Water and Power Development Authority (WAPDA), Water and Sanitation Agency (WASA), and Pakistan Telecommunication Company Limited (PTCL), etc. may direct sanction for the utility services without any delay. Likewise, the nongovernmental organizations (NGO's) should be incorporated to establish different cottage and small-scale industries and/or to provide training in migrant generating locations. Similarly, innovative industrial estate patterns in secondary and tertiary cities could be introduced with an industrial tax-free policy to attract investors.

The governing bodies should improve Sindh secondary and tertiary cities as centers of innovation, entrepreneurship, and sources for socioeconomic services and opportunities through prioritizing investments helpful for local economic development, and opportunities for public-private partnerships in urban development and urban services. Also, the local revenue generation and the financial 
management system of Sindh secondary and tertiary cities should be upgraded to capacitate local economic development. Whereas traditional markets should be modernized to attract more private investors to diversify and revitalize economic growth so that the skilled migrated workforce could be attracted. Similarly, broadening the quantity and extent of high-quality research universities, professional development courses, and internships to incubate youth to earn more in their native places could decrease rural push. Backing up the growth of high-quality research universities can offer more job options and evolving further the entrepreneurial values of migration generating cities. In addition, information regarding accessible fiscal utilities, hoarding programs, and work-related counseling should be exchanged with migrants to boost local commerce in the profitable economic divisions.

\subsection{Policy Recommendations for Socio- cultural Pull-factors}

The adequate amenities and facilities should be made accessible in Sindh secondary and tertiary cities, while the development authorities should be empowered to manage such facilities to curtail urbanization flow. A most critical element in curtailing urbanization is the formulation of a regulatory framework. Thus, enhancements in rural administrations could be made to effectively deal with issues like rural migration, re-planning, reconstructing, and rehabilitating substandard or insanitary rural communities. Also, improvements in the supply of amenities and services along with a systematic process is the need of time to organize and sustain them. Emphasis should be given to aging and young as their inclusion is crucial to the rural civic vitality and viability.

The decision-makers should evade partiality towards cities. Cities generating a substantial amount of agriculture-based revenue ought to have all essential necessities to support a quality lifestyle. Also, the accessibility and connectivity of remote locations with various primary/metropolitan cities should be ensured. It was found that
Hyderabad's civic amenities and facilities, bright city lights, theaters, shopping malls, sports academies, metalled roads, parks, etc. attract thousands of youth from Sindh secondary and tertiary cities. Therefore, the provision of amenities and urban services is much needed. Along with other facilities, lack of educational institutes was also observed as a strong urban pull. Thus, the development of higher education institutions for medical, engineering, and social sciences in Sindh secondary and tertiary cities was proposed to decline migrant's influx. Whereas, maintaining and promoting quality schooling in terms of services and excellent education was proposed to attract young families towards their origins. Also, community-based development was suggested to be empowered to enhance public access to educational opportunities to best harness their indigenous skills. At last, academia and qualified professionals were suggested to increase research practices, especially with the emphasis on Sindh secondary and tertiary cities as a means for finding solutions and new directions for development.

\section{Conclusion}

The phenomenon of rapid urbanization has become an ever-increasing and alarming urban problem in Pakistan's context as urban development is being prioritized so that the cities could become progressive, resilient, and sustainable. Though urbanization is crucial to attract valuable human resource towards the cities, but it is only fruitful if carried out in a planned and controlled manner. Due to migration-led rapid increase in the urban population of Hyderabad district, almost all vacant land in the urban cores and even open spaces have been metamorphosed into residential use. Now, the trend is affecting the valuable agricultural lands of Hyderabad rural Taluka as the agricultural land is being converted into residential and commercial uses. Consequently, the ever-increasing and unharnessed immense urbanization results in several urban issues of which, overpopulation, sprawl, ever-expanding slums, and overburdened urban infrastructure, are a few prime 
examples. To curtail the higher urbanization rate, questions like 'what factors are responsible for this phenomenon?'; 'to what extent they are contributing?'; and 'how urbanization could be controlled?' needs to be answered. This study attempted to answer these questions and aimed to propose policy recommendations via the identification of significant pull-factors by measuring their respective impacts. Contrary to the sociocultural pull-factors, results suggested that economic pull-factors are more responsible for uncontrolled urbanization in Hyderabad, Pakistan. The economic pull-factors including better employment opportunities, higher income probability, and job security creates a strong urban-pull and portray Hyderabad as an eye-catching destination for economic migrants and job seekers. While socio-cultural pull-factors such as easy access to facilities, better outlook and hope for the future, and comfortable and diverse lifestyle makes urbanpull stronger that draws economically stable families just to enjoy an urban lifestyle.

This study must acknowledge its limitations. Urbanization is a multidimensional process involving 4 factors (pull, push, stay, return) and simply pullfactors standalone cannot unfold the whole urbanization scenario. However, this can be achieved by integrating other factors and their associated variables for better understanding. The study has tried its best to highlight the core encouragers of urbanization in the context of Hyderabad, Pakistan, wherein, the proposed policy recommendations could assist urban planners and policymakers to formulate an urbanization control policy. Furthermore, the methodology could be imitated to estimate the factors of urbanization in other urban areas. Moreover, the statistical model used in this study could be expanded in future to incorporate emerging pull-factors so that the role of urban pull-factors could be understood in several cities of developing countries struggling to cope with this dilemma.

AUthor CONTRIBUTion: Hassam Bin Waseem (HBW), Mir Aftab Hussain Talpur (MAHT)
Data curation: HBW.

Methodology: HBW, MAHT.

Software: HBW.

Supervision: MAHT.

Writing - original draft: HBW.

Writing - review \& editing: HBW, MAHT.

DATA AVAILABILTY STATEMENT: A dataset collected through questionnaire surveys by HBW was used in this study.

\section{CONFLICT OF INTEREST: None}

FUNDING: This study was not funded by any public/private funding agency.

\section{Reference}

[1] D. Wang, "Socioeconomic characteristics of rural urbanization in Southern Jiangsu, China," International Journal of Social Economics, vol. 26 no. 1/2/3, pp. 290-297, 1999.

[2] M. T. Turan and A. Beşirli, "Impacts of urbanization process on mental health," Anatolian Journal of Psychiatry, vol. 9, pp. 238-243, 2008.

[3] N. N. A. Aziz, W. H. A. W. Hassan, and N. A. Saud, "The Effects of Urbanization towards Social and Cultural Changes among Malaysian Settlers in the Federal Land Development Schemes (FELDA), Johor Darul Takzim," Procedia - Social and Behavioral Sciences, vol. 68, pp. 910-920, 2012/12/19/ 2012.

[4] H. Akhter, "Rural-urban Linkages in Bangladesh: Emerging Scenario of a Secondary Urban Center," Dhaka University Journal of Earth and Environmental Sciences, vol. 3, no. 1, 11-08-2014 2014.

[5] A. Shakoori, "Regionalism versus centralism: an analysis of failure of regional planning in Iran," Journal of Social and Economic Development, vol. 18, 09/09 2016.

[6] J. R. Harris and M. P. Todaro, "Migration, Unemployment and Development: A Two-Sector Analysis," The American Economic Review, vol. 
60, no. 1, pp. 126-142, 1970.

[7] J. Van Ommeren, G. J. Van Den Berg, and C. Gorter, "Estimating the Marginal Willingness to Pay for Commuting," Journal of Regional Science, vol. 40, no. 3, pp. 541-563, 2000/08/01 2002.

[8] J. S. Zax, "When is a move a migration?," Regional Science and Urban Economics, vol. 24, no., pp. 341360, July 19931994.

[9] A. van der Veen and G. Evers, "A simultaneous model for regional labor supply, incorporating labor force participation, commuting and migration," Socio-Economic Planning Sciences, vol. 17, no. 5, pp. 239-250, 1983/01/01/ 1983.

[10] B. Swain, "The Impact of Urbanisation on Crop-Livestock Farming System: A Comparative Case Study of India and Bangladesh," Journal of Social and Economic Development, vol. 19, pp. 161-180, 2017.

[11] H. Crow, "Factors Influencing Rural Migration Decisions in Scotland: An Analysis of the Evidence," Scottish Government Social Research2010.

[12] A. Ishtiaque and M. Sofi Ullah, "The Influence of Factors of Migration on the Migration Status of Rural-Urban Migrants in Dhaka, Bangladesh," Human Geographies vol. 07, no. 2, pp. 45-52, 2013.

[13] A. Haas and L. Osland, "Commuting, Migration, Housing and Labour Markets: Complex Interactions," Urban Studies, vol. 51, no. 3, pp. 463-476, 2014/02/01 2014.

[14] A. Kährik, J. Temelová, K. Kadarik, and J. Kubeš, "What attracts people to inner city areas? The cases of two postsocialist cities in Estonia and the Czech Republic," Urban Studies, vol. 53, no. 2, pp. 355-372, 2016/02/01 2015.

[15] G. W. Jones, "Population Situation Analysis of Pakistan," United Nations Population Fund (UNFPA)2016.

[16] M. W. Siddiqi, "Rural-urban migration
(A case study of Lahore district)," Pakistan research repository. University of the Punjab. Lahore, Pakistan 2004.

[17] S. He, "Consuming urban living in 'villages in the city': Studentification in Guangzhou, China," vol. 52, no. 15, pp. 2849-2873, 2015.

[18] F. Lanrewaju, "Urbanization, housing quality and environmental degeneration in Nigeria," Journal of Geography and Regional Planning, vol. 5, no. 16, pp. 422-429, 2012.

[19] C. R. Farrell, "Immigrant suburbanisation and the shifting geographic structure of metropolitan segregation in the United States," Urban Studies, vol. 53, no. 1, pp. 57-76, 2016/01/01 2014.

[20] J. Zhu and Y. Guo, "Fragmented Periurbanisation Led by Autonomous Village Development under Informal Institution in High-density Regions: The Case of Nanhai, China," Urban Studies, vol. 51, no. 6, pp. 1120-1145, 2014/05/01 2013.

[21] D. Webster and L. Muller, "Challenges of peri-urbanization in the Lower Yangtze Region: The case of the Hangzhou-Ningbo Corridor," 2002.

[22] T. G. MacGee, "The Emergence of Desakota Regions in Asia : Expanding A Hypothesis," The Extended Metropolis : Settlement Transition in Asia, no. 3-24, 19911991.

[23] M. J. Greif, F. N.-A. Dodoo, and A. Jayaraman, "Urbanisation, Poverty and Sexual Behaviour: The Tale of Five African Cities," Urban Studies, vol. 48, no. 5, pp. 947-957, 2011/04/01 2010.

[24] M. Qasim, M. M. Anees, U. Ghani, J. Malik, M. Khalid, and A. Bashir, "Environment Degradation Cause By Urbanization in Pakistan (A review Paper)," Bulletin of Energy Economics (BEE), The Economics and Social Development Organization (TESDO), vol. 2, no. 3, pp. 62-71, 2014.

[25] D. E. Dowall and P. D. Ellis, "Urban 
Hassam (et al.), Impact Assessment of Urban Pull-factors on Uncontrolled Urbanization: Evidence from Pakistan

Land and Housing Markets in the Punjab, Pakistan," vol. 46, no. 11, pp. 2277-2300, 2009.

[26] L. Morinière, "Environmentally Influenced Urbanisation: Footprints Bound for Town?," Urban Studies, vol. 49, no. 2, pp. 435-450, 2012/02/01 2011.

[27] (2017). Provisional Summary Results of 6th Population and Housing Census2017.

[28] Government of Sindh. (2008). Hyderabad Master Plan 2007-27 PrePlanning Report.

[29] F. Van Noorloos and M. Kloosterboer, "Africa's new cities: The contested future of urbanisation," Urban Studies, vol. 55, no. 6, pp. 1223-1241, 2018/05/01 2017.

[30] J. R. Logan, "People and plans in urbanising China: Challenging the topdown orthodoxy," Urban Studies, vol. 55, no. 7, pp. 1375-1382, 2018/05/01 2018.

[31] (1999). 1998 Census Report of Hyderabad.

[32] Ministry of Climate Change, Government of Pakistan. (2015). National Report of Pakistan for HABITAT III.

[33] Y. Zhan, "The urbanisation of rural migrants and the making of urban villages in contemporary China," Urban Studies, vol. 55, no. 7, pp. 1525-1540, 2018/05/01 2017.

[34] R. Grant, "Sustainable African Urban Futures: Stocktaking and Critical Reflection on Proposed Urban Projects," American Behavioral Scientist, vol. 59, no. 3, pp. 294-310, 2015/03/01 2014.

[35] D. Hattingh, B. Russo, A. Sun-Basorun, and A. V. Wamelen, "The rise of the African consumer: A report from McKinsey's Africa Consumer Insights Center," 2012.

[36] KMPG, "The role of cities in Africa's rise," KMPG International Digital Reports2012.

[37] N. Ahmad, "Choice of Location and
Mobility Behaviour of Migrant Households in a Third World City," vol. 29, no. 7, pp. 1147-1157, 1992.

[38] Z. Li and Z. Liang, "Gender and job mobility among rural to urban temporary migrants in the Pearl River Delta in China," Urban Studies, vol. 53, no. 16, pp. 3455-3471, 2016/12/01 2016.

[39] N. Verter and S. Darkwah, "Determinants of International Migration: The Nigerian Experience," Acta Universitatis Agriculturae et Silviculturae Mendelianae Brunensis, vol. 62, no. 2, pp. 321-327, 2014.

[40] B. P. George and A. Shyamsundar, "The Factors that Affect Indian Migrants' Decision to Stay in or Counter Migrate from the United States: A Study with Special Reference to the Role of Tourism Related Imagery as a Determinant," Journal of Identity and Migration Studies, vol. 1, no. 2, 2007.

[41] S. F. McCool and L. E. Kruger, "Human Migration and Natural Resources: Implications for Land Managers and Challenges for Researchers," United States Department of Agriculture, Forest Service, Pacific Northwest Research Station2001.

[42] B. E. Amphune and Y. D. Enaro, "Urban Livelihoods of Rural to Urban Migrants: A Case Study of Wolaita Sodo Town, Southern Ethiopia," presented at the 2nd National Workshop of Research and Community Services, Wolaita Sodo University, 2012.

[43] P. B. Cobbinah, M. O. Erdiaw-Kwasie, and P. Amoateng, "Africa's urbanisation: Implications for sustainable development," Cities, vol. 47, pp. 62-72, 2015.

[44] K. S. Sridhar, R. A. Venugopala, and S. Pavan, "Is it Push or Pull? Recent Evidence from Migration into Bangalore, India," Journal of International Migration and Integration, vol. 14, no. 2, pp. 287-306, 2013.

[45] B. M. Chakma and A. A. Akhy, "Hill to 
Plain: Causes and Impacts of Internal Migration of Indigenous Peoples in Bangladesh," Sociology Mind, vol. 05, no. 04, pp. 268-275, 2015.

[46] K. Thet, "Pull and Push Factors of Migration A Case Study in the Urban Area of Monywa Township , Myanmar.pdf>," World of Statistics, vol. 1, no. 4, 2014.

[47] P. Martin and G. Zuercher, "Managing migration: The global challenge," Population bulletin, vol. 63, pp. 3-20, 03/01 2008.

[48] P. Grabova, B. Dosti, and E. Pojani, "Effects of Economic Crisis on Migration - Evidence from Albania," European Scientific Journal, vol. 9, no. 22, 2013.

[49] D. Zweig, C. S. Fung, and D. Han, "Redefining the Brain Drain," Science, Technology and Society, vol. 13, no. 1, pp. 1-33, 2008.

[50] N. Farah, M. I. Zafar, and N. Nawaz, "Socio-Economic and Cultural Factors Affecting Migration Behavior in District Faisalabad, Pakistan," Pakistan Journal of Life and Social Sciences, vol. 10, no. 1, pp. 28-32, 2012.

[51] J. G. Adewale, "Socio-Economic Factors Associated with Urban-Rural Migration in Nigeria: A Case Study of Oyo State, Nigeria," Journal of Human Ecology, vol. 17, no. 1, pp. 13-16, 2005/01/01 2005.

[52] E. Kerselaers, E. Rogge, E. Vanempten, L. Lauwers, and G. Van Huylenbroeck, "Changing land use in the countryside: Stakeholders' perception of the ongoing rural planning processes in Flanders," Land Use Policy, vol. 32, pp. 197-206, 2013.

[53] G. Thondhlana, "Land acquisition for and local livelihood implications of biofuel development in Zimbabwe," Land Use Policy, vol. 49, pp. 11-19, 2015.

[54] T. A. Tran, "Land use change driven outmigration: Evidence from three flood- prone communities in the Vietnamese Mekong Delta," Land Use Policy, vol. 88, 2019.

[55] Abbas Tashakkori and C. Teddlie, Abbas Tashakkori and C. Teddlie, Eds. Handbook of Mixed Methods in Social \& Behavioral Research. SAGE Publications, 2013.

[56] A. Joshua Remi, A.-A. Ibraheem Adegoke, and O. Nurain. A, "An Appraisal of the Factors Influencing Rural-Urban Migration in Some Selected Local Government Areas of Lagos State Nigeria," Journal of Sustainable Development, vol. 4, no. 3, 2011.

[57] T. Yamane, Statistics : an introductory analysis (no. Accessed from https://nla.gov.au/nla.cat-vn1136113).

New York: Harper and Row, 1967, p. 915.

[58] J. Hartley, "Some thoughts on Likerttype scales," International Journal of Clinical and Health Psychology, vol. 14, no. 1, pp. 83-86, 2014.

[59] G. K. Uyanık and N. Güler, "A Study on Multiple Linear Regression Analysis," Procedia - Social and Behavioral Sciences, vol. 106, pp. 234-240, 2013/12/10/ 2013.

[60] P. Bahuguna and O. K. Belwal, "Regression Model Approach for OutMigration on Demographic Aspects of Rural Areas of Pauri Garhwal," International Journal of Management and Social Sciences Research (IJMSSR), vol. 2, pp. 175-182, 2013.

[61] T. Breusch and A. Pagan, "A Simple Test for Heteroscedasticity and Random Coefficient Variation," Econometrica, vol. 47, no. 5, pp. 1287-94, 1979.

[62] Roger Koenker and G. B. Jr., "Robust Tests for Heteroscedasticity Based on Regression Quantiles " Econometrica, vol. 50, no. 1 pp. 43-61, 1982.

[63] N. Ahmad, Z. Hussain, M. H. Sial, I. Hussain, and W. Akram, "Macroeconomic Determinants of 
Hassam (et al.), Impact Assessment of Urban Pull-factors on Uncontrolled Urbanization: Evidence from Pakistan

(pp. 37 - 52)

International Migration from Pakistan " Pakistan Economic and Social Review, vol. 46, no. 2, pp. 85-99, 2008.

[64] L. Zi, "Urbanization and Economic Growth in China-An Empirical Research Based on VAR Model," International Journal of Economics and Finance, vol. 9, p. 210, 02/20 2017.

[65] C. Ajaero, I. Madu, and A. Mozie, "Appraisal of The Factors of Rural-
Urban Migration In Southeastern Nigeria," Innovare Journal of Social Sciences, vol. 1, pp. 1-8, 12/21 2013.

[66] N. Ahmad, Z. Hussain, M. Sial, H. Ijaz, and W. Akram, "Macroeconomic Determinants of International Migration From Pakistan," Pakistan Economic and Social Review, vol. 46, pp. 85-99, 04/01 2008. 